FACTA UNIVERSITATIS

Series: Physical Education and Sport, Vol. 17, No 3, 2019, pp. 515 - 522

https://doi.org/10.22190/FUPES191205045B

Research article

\title{
CHANGES IN SPEED, AGILITY AND BODY COMPOSITION OF TOP-RANKED FEMALE HANDBALL PLAYERS DURING THE PLAYING SEASON
}

\author{
UDC 796.012.322
}

\section{Ivana Bojić ${ }^{1}$, Nenad Stojiljković ${ }^{1}$, Zoran Valdevit ${ }^{2}$, Marina Veličković ${ }^{1}$, Dušan Nikolić ${ }^{1}$}

${ }^{1}$ Faculty of Sport and Physical Education, University of Niš, Niš, Serbia

${ }^{2}$ Faculty of Sport and Physical Education, University of Belgrade, Belgrade, Serbia

\begin{abstract}
Handball is a dynamic Olympic sport dominated by acyclic movements (sudden changes in direction, jumps, landings, contacts between the players, etc.) with speed and agility playing an important role in their successful realization. Our aim was to establish which changes occurred in the body composition, speed and agility of topranked female handball players during the playing season. The parameters for estimating body composition were: body mass, body mass index (BMI), the percentage of muscle and fat. The ability to achieve speed (in 5, 10 and 30m sprints) and agility (new envelope test without a ball, straight slalom run without a ball and Straight slalom run with a ball, zig-zag with and zig-zag without a ball) was estimated with the portable timing system. The differences between the initial and the final measurements were established with the Student's t-test. The results obtained show that there were statistically significant changes and weaker results in almost all the tested variables. The only improvements were detected in the maximum speed in $30 \mathrm{~m}$ sprint and the agility without a ball (new envelope test and slalom run without a ball). It is recommended that the training plan should be carefully devised (the activities of the high intensity load should be applied throughout the season) as well as the plan for proper sports nutrition (body mass should be reduced with simultaneous increase in the muscular mass component).
\end{abstract}

Key words: Body Composition, Speed, Agility, Changes, Female Handball Players

Received December 05, 2019/ Accepted December 19, 2019

Corresponding author: Ivana Bojić

Faculty of Sport and Physical Education, University of Niš, Čarnojevića 10a, 18000 Niš, Serbia

Phone: +381 $18510900 •$ E-mail: bojicka2003@yahoo.com

() 2019 by University of Niš, Serbia | Creative Commons License: CC BY-NC-ND 


\section{INTRODUCTION}

Modern handball belongs to the group of anaerobic and aerobic games dominated by acyclic movements with sudden changes of direction, and the high-intensity load throughout the game. The success of realization of the technical and tactical activities demands that the players have high levels of basic and specific motor abilities (precision, speed, agility, explosive power, endurance, etc.), psychological stability, as well as excellent physiological and functional abilities. Achieving and maintaining the highest levels of success in female handball players implies a multidisciplinary approach in the training process plan and programme preparation. This involves the application of the knowledge in different but closely-knit-to-sport sciences such as physiology of exercise, sports medicine, sports psychology, sociology and others. While planning long-term training programmes for a team, handball coaches, together with strength and conditioning coaches, athletic coaches and sports medicine doctors, should all have access to the data on the physical and physiological abilities of the players.

Technical abilities of the players, tactics, many other factors and abilities have a key role in handball. Since it is a dynamic contact game, there are numerous sudden changes in offense and defense, short and swift movements, sudden direction changes, jumps, various shots and duels. It takes excellent starting speed and sprint ability for swift offenses that so often happen during the game. Physical ability, such as coordination, strength, agility, balance and elasticity (Dopsaj, 1994), is also very important when it comes to the throwing movements preceded by jumps, falls, turns and bends. To achieve advantage in counterattacks, duels and other technical and tactical demands, motor abilities, speed and agility are crucial (Eler \& Eler, 2018; Young \& Rogers, 2014; Hermassi, Fadhloun, Chelly, \& Bensbaa, 2011; Granados, Izquierdo, Ibañez, Bonnabau, \& Gorostiaga, 2007). Since speed and agility tests are in close connection with the very structure of the handball game, they are often used for estimating the most important performance parameters of the players. The analysis of the types of movements and the speed of the top-ranked female players during the games (Michalsik, Madsen, \& Aagaard, 2013) shows that the shortest distance during the game is covered with low intensity (standing and walking $4 \mathrm{~km}$ ), moderate intensity (slow running, sideways and backward movements $9-12 \mathrm{~km}$ ), whereas the greatest distance is covered with high-intensity running and sprint $(15.5-22 \mathrm{~km})$. It should be mentioned that modern handball aims at creating polyvalent female players who can play successfully in all the positions on the team. However, the demands and the tasks linked to each position are different, which makes it difficult to establish the influence that anthropological characteristics of the player have on the successful performance in this sport (Eler \& Eler, 2018; Bojić, Kocić, \& Valdevit, 2019).

It is widely known that body composition influences physical performances in any sport, handball as well. Gorostiaga, Granados, Ibanez, \& Izquierdo (2005) showed that top-ranked handball players were heavier, had more muscle mass and higher body mass index (BMI) compared to amateurs. They also concluded that higher values of body mass, muscle mass in particular, were extremely useful in handball. Physical and physiological characteristics, with the players' performance in situational conditions (competitions), have been the subject of many studies (Manchado, Cortell-Tormo, \& Tortosa-Martınez, 2018; Moss, McWhannell, Lars Bojsen Michalsik, \& Twist, 2015; Manchado, Tortosa-Marti’Nez, Vila, Ferragut, \& Platen, 2013; Milanese, Piscitelli, Lampis, \& Zancanaro, 2012, 2011; Ziv \& Lidor, 2009). 
They have proven that taller players are more successful in the activities which include the strength component. In athletic disciplines which involve throwing, as in sport games such as handball, volleyball, basketball and water polo, the athletes are taller, heavier and more muscular than those athletes who are not in disciplines and sports that involve throwing. This was supported by the facts that muscular mass had a very important positive influence on the throwing performance and isometric strength (Van der Tillaar, \& Ettema, 2003; Zapartidis et al., 2009). Morphological characteristics also play a significant role in achieving success in handball. Modern handball, although aiming at the polyvalence of the players, requires a specific body composition for a specific player's position on a team. Research has proven that there are differences in body composition of the players depending on their playing positions (Bojić et al., 2019; Weber, Wegner, \& Wagner, 2018; Michalsik et al., 2013; Urban \& Kandráč, 2013; Milanese et al., 2011; Čižmek, Ohnjec, Vučetić, \& Gruić, 2010). It has been noticed that in the selection process the positions of goalkeepers and backs are given to the players who are more mature, with better anthropometric predispositions (the taller ones with longer extremities) and in better physical shape. Shorter players are usually positioned as wings and pivots. Generally speaking, it appears that anthropometric characteristics and maturity serve the purpose of direct and/or indirect selection parameters among the players. However, this strategy is risky, since anthropometric and maturity status changes over the years. As opposed to the pre-adolescent period, the differences in the body composition of mature top-ranked female handball players are more distinctive. The players in the goalkeeper position are higher with a larger percentage of subcutaneous fatty tissue in the overall body mass (Grujić, 2016; Šibila \& Pori, 2009). Pivots and backs are very similar in their morphological characteristics, with pivots having higher values of muscular mass, fatty tissue and more prominent transversal measurements (Taborský, 2007; Srhoj, Marinović, \& Rogulj, 2002). Contrary to all the other players, wings are shorter, with lower body mass and subcutaneous fatty tissue values (Šibila \& Pori, 2009). As a rule, top-ranked players have more distinctive longitudinal and transversal upper extremity measurements, higher values of the muscle mass and lower values of BMI (Massuça \& Fragos, 2015).

There has not been much research on the ways training processes and competitions influence changes in the body composition of handball players (Milanese et al., 2012; Granados et al., 2007; Gorostiaga et al., 2005). The results of these studies showed that during the playing season the changes in body mass percentage are positively correlated with the changes in the maximum strength and muscular strength, that is, the higher the values of the muscular mass, the lower the percentage of the fatty tissue.

The aim of our research was to determine changes in the body composition, speed and agility of top-ranked female handball players during the playing season.

\section{METHODS}

\section{Participants}

Fourteen top-ranked female handball players of the H.C. "Naisa" from Niš (aged $22.7 \pm 2$ years; height $173.7 \pm 6 \mathrm{~cm}$; body mass $67.5 \pm 8 \mathrm{~kg}$, Mean $\pm \mathrm{SD}$ ) participated in the research. All of them competed in the Serbian Super League in the season 2016/17. All the participants had a minimum of three years player experience. 
Testing was conducted before the beginning of the championship (on September 6, 2016) and at the end of competition within the Serbian Super League (on May 23, 2017). Both testing protocols were organized in the morning.

\section{Measures}

The body composition was measured with "Omron BF511" scales which provided precise data on the body mass (in $\mathrm{kg}$ ), fat percentage (in \%), muscle percentage (in \%), BMI $\left(\mathrm{kg} / \mathrm{m}^{2}\right)$.

The players' speed was measured through $5 \mathrm{~m}, 10$, and $30 \mathrm{~m}$ sprints (in s), whereas agility was measured with the following tests: new envelope without a ball, straight slalom run without and straight slalom run with a ball, zig-zag with a ball and zig-zag without a ball (in s). The speed and agility were measured with the portable timing system (The Witty System, Microgate Italy).

\section{Procedures}

The differences between the initial (at the beginning of the season) and the final measurements (at the end of the season) of the examinees were established with the Student's t-test. The level of the significance was set at $\mathrm{p}<.05$. The SPSS version 12 was used for the statistical data analysis.

\section{RESULTS}

The differences between the initial (at the beginning of the season) and the final measurements (at the end of the season) of the participants were determined with the Student's t-test. The results in Table 1 show that there are statistically significant changes in almost all the tested variables, except for the muscle percentage test $(p=.084)$. Comparing the mean values at the beginning and at the end of the experiment, it can be noticed that the body mass values, the body mass index values as well as the fat percentage values are higher at the end of the season, which is considered to be a deterioration in the results. Similar to our findings, Gorostiaga, Granados, Ibanez, Gonzalez-Badillo, \& Izquierdo (2005) obtained results which showed that the players' body mass values had slightly increasing during the season but had fallen to the starting values towards the end of the season. Contrary to our research, some previous studies have determined positive changes in the target values of the body composition of the top-ranked female players which were influenced by the playing season (Milanese et al., 2012; Granados et al., 2007).

Table 1 Differences in the body composition of the female handball players during the season (Student's t-test)

\begin{tabular}{llccrc}
\hline Measurements & $\mathrm{N}$ & Mean (1. testing) & Mean (2. testing) & T-value & $\mathrm{p}$ \\
\hline Body mass (kg) & 14 & 66.58 & 68.39 & -3.26 & $\mathbf{. 0 0 6}$ \\
BMI (kg/m 2$)$ & 14 & 22.01 & 22.69 & -3.74 & $\mathbf{. 0 0 2}$ \\
Fat $(\%)$ & 14 & 27.89 & 29.41 & -3.42 & $\mathbf{. 0 0 5}$ \\
Muscles $(\%)$ & 14 & 31.14 & 30.66 & 1.87 & .084 \\
\hline
\end{tabular}

The level of the significance set at level: $\mathrm{p} \leq .05$ 
Table 2 shows the changes in speed and agility of the female handball players during the season. The results obtained show that there are statistically significant differences in speed in the $30 \mathrm{~m}$ Sprint test $(\mathrm{p}=.045)$ and in all agility tests, except for the zig-zag test without a ball $(\mathrm{p}=.175)$. The players had better results at the end of the season only on the $30 \mathrm{~m}$ sprint test, new envelope test without a ball and slalom run with a ball. In all the other tests their results were worse in the second measuring, that is, at the end of the season.

Table 2 Differences in speed and agility of the female handball players during the season (Student's t-test)

\begin{tabular}{|c|c|c|c|c|c|c|}
\hline & Measurements & $\mathrm{N}$ & Mean (1. testing) & Mean (2. testing) & T-value & $\mathrm{p}$ \\
\hline \multirow{3}{*}{ Speed } & Sprint $5 \mathrm{~m}(\mathrm{~s})$ & 14 & 1.28 & 1.25 & 1.33 & .203 \\
\hline & Sprint $10 \mathrm{~m}(\mathrm{~s})$ & 14 & 2.12 & 2.09 & 1.23 & .238 \\
\hline & Sprint $30 \mathrm{~m}(\mathrm{~s})$ & 14 & 5.03 & 4.91 & 2.17 & .045 \\
\hline \multirow{5}{*}{ Agility } & New envelope test without a ball (s) & 14 & 7.94 & 7.52 & 3.36 & .004 \\
\hline & Straight slalom without a ball (s) & 14 & 7.87 & 8.29 & -3.42 & .003 \\
\hline & Straight slalom with a ball (s) & 14 & 8.79 & 6.32 & 6.92 & .000 \\
\hline & Zig-zag 100 without a ball (s) & 14 & 5.73 & 5.85 & -1.42 & .175 \\
\hline & Zig-zag 100 with a ball (s) & 14 & 5.96 & 7.10 & -5.24 & .000 \\
\hline
\end{tabular}

There have not been a lot of studies into the changes in physical abilities (speed and agility) of the top-ranked female players during the season. Similar results were obtained only by Granados, Izquierdo, Ibanez, Ruesta, \& Gorostiaga (2008), who did not find any statistically significant differences in the maximum running speed (the $5 \mathrm{~m}$ and $15 \mathrm{~m}$ tests) during the season among 16 top-ranked Spanish female handball players.

\section{DISCUSSION}

Handball is a dynamic game of high intensity and tempo. Therefore, it requires a specific morphological composition, as well as excellent physical and psychological readiness of female players so that they could successfully realize almost all the technical and tactical activities. The female handball players who participated in this research competed at the highest levels of the Serbian Super League competition (season 2016/17), at the end of which they were third-ranked. Apart from this domestic championship (18 games), the play-off (10 games) and the Serbian Cup (6 games), they also competed in the European Challenge Cup ( 2 games). A large number of games, 38 in total, required a continuous training process, maintaining and improving the readiness and fitness of the players throughout the season.

The results obtained in our research show that the female handball players had unexpectedly statistically worse results regarding their body mass and motor ability, agility, at the end of the season. The body mass values, the body mass index and the fat percentage were significantly higher in the second measuring. The only parameter that saw no significant change was muscle mass (muscle percentage), which can be justified by the influence of specific technical and tactical activities done in the training process and competition. When it comes to motor abilities, the improvement in results appeared only in the maximum running speed in $30 \mathrm{~m}$, new envelope test (without a ball) and slalom run with 
a ball, whereas in all the other tests the players had poor results at the end of the season. Having in mind the high and intense load that the players had to cope with during the season, the results which were worse at the end of the season came as a surprise. The possible causes of such a failure might be a poorly-planned and guided training process, disparity in the exposure to the load in the training sessions and the games, differences in the time spent in the game, as well as irregular nutrition (the imbalance between the energy intake and consumption). It should also be mentioned that motivation had a significant role because the players were less interested in the last testing since the playing season was about to finish.

\section{CONCLUSION}

The aim of the research was to determine the changes in the body composition, speed and agility of the top-ranked female handball players during the season. The obtained results were unexpected and indicate that the playing season brought about significant deterioration in the body composition values (the increase in the body mass, the body mass index and the fat percentage) and the agility of the examined female handball players. The muscle mass percentage values and the values of one test for the agility without a ball (the zig-zag 100 without a ball) remained statistically unchanged. Better results at the end of the season were obtained on the $30 \mathrm{~m}$ maximum running test and the agility test without a ball (new envelope test).

Following the features of modern handball, competitions and training activities should be considered a high-intensity stimulus aiming at improving certain aspects of the physical condition and anthropometric characteristics of top-ranked handball players. However, from the results we obtained, we believe that a proper selection and application of various means and high-intensity activity load exercises should be utilized in the training sessions throughout the season. On the other hand, this implies that less focus should be placed on low-intensity load exercises, except for the microcycles of the players' recovery. Having in mind the fact that not all the players are equally active in the training sessions and games, that they have different play time in the game, and different demands regarding their position on a team, it is necessary to pay attention to the optimal individual load and to recommend professional nutrition planning so that the body fat can be reduced without losing the muscle mass. It is essential to do further research into the most effective and most appropriate stimuli within the training process with the aim of improving the physical shape and handball performance of top-ranked female handball players.

\section{REFERENCES}

Bojić, I., Kocić, M., \& Valdevit, Z. (2019). Differences in body composition and motor abilities among female handball players relating to positions in the team. In: N. Stojiljković (Ed.), 22 Scientific Conference "FIS Communications 2019” in Physical Education, Sport and Recreation (pp. 91-98). Niš: Faculty of Sport and Physical Education, University of Niš.

Čižmek, A., Ohnjec, K., Vučetić, V., \& Gruić, I. (2010). Morphological differences of elite Croatian female handball players according to their game position. Hrvatski športskomedicinski vjesnik, 25(2), 122-127.

Dopsaj, M. (1994). Extent of flexibility among athletes in different sports games: Soccer, volleyball, basketball and handball. Facta Universitatis Series Physical Education, 1(1), 51-60. 
Eler, N., \& Eler, S. (2018). The effect of agility exercises on the COD speed and speed in terms of the frequency of the training. Universal Journal of Educational Research, 6(9), 1909-1915.

Gorostiaga, E.M., Granados, C., Ibanez, J., \& Izquierdo, M. (2005). Differences in physical fitness and throwing velocity among elite and amateur male handball players. International Journal of Sports Medicine, 26, 225-232.

Gorostiaga, E.M., Granados, C., Ibanez, J., Gonzalez-Badillo, J.J., \& Izquierdo, M. (2005). Effects of an entire season on physical fitness changes in elite male handball players. Medicine \& Science in Sports \& Exercise, 38(2), 357-366.

Granados, C., Izquierdo, M., Ibañez, J., Bonnabau, H., \& Gorostiaga, E. (2007). Differences in physical fitness and throwing velocity among elite and amateur female handball players. International Journal of Sports Medicine, 28(10), 860-867.

Granados, C., Izquierdo, M., Ibanez, J., Ruesta, M., \& Gorostiaga, E.M. (2008). Effects of an entire season on physical fitness in elite female handball players. Medicine \& Science in Sports \& Exercise, 40, 351-361.

Grujić, S. (2016). Modelne karakteristike mladih rukometaša u odnosu na morfološka i motorička obeležja. (Model characteristics of young handball players in relation to morphological and motor features). $\mathrm{PhD}$ Thesis, Novi Sad: University Educons, Faculty for Sport and Tourism in Novi Sad. In Serbian

Hermassi, S., Fadhloun, M., Chelly, M.S., \& Bensbaa, A. (2011). Relationship between agility T- test and physical fitness measures as indicators of performance in elite adolescent handball players. Pedagogics, Psychology, Medical-Biological Problems of Physical Training and Sports, 5, 125.

Manchado, C., Tortosa-Marti'Nez, J., Vila, H., Ferragut, C., \& Platen, P. (2013). Performance factors in women's team handball: physical and physiological aspects-a review. The Journal of Strength and Conditioning Research, 27(6), 1708-1719.

Manchado, C., Cortell-Tormo, J.M., \& Tortosa-Martinez, J. (2018). Effects of two different training periodization models on physical and physiological aspects of elite female team handball players. The Journal of Strength and Conditioning Research, 32(1), 280-287.

Massuça, L., \& Fragoso, I. (2015). Morphological characteristics of adult male handball players considering five levels of performance and playing position. Collegium Antropologicum, 39 (1), 109-118.

Michalsik, L., Madsen, K., \& Aagaard, P. (2013). Match performance and physiological capacity of female elite team handball players. International Journal of Sports Medicine, 35(7), 595-607.

Milanese, C., Piscitelli, F., Lampis, C., \& Zancanaro, C. (2011). Anthropometry and body composition of female handball players according to competitive level or the playing position. Journal of Sports Sciences, 29(12), 1301-1309.

Milanese, C., Piscitelli, F., Lampis, C., \& Zancanaro, C. (2012). Effect of a competitive season on anthropometry and three-compartment body composition in female handball players. Biology of Sport, 29, 199-204.

Moss, S.L., McWhannell, N., Lars Bojsen Michalsik, L.B., \& Twist, C. (2015). Anthropometric and physical performance characteristics of top-elite, elite and non-elite youth female team handball players. Journal of Sports Sciences, 33(17), 1780-1789.

Srhoj, V., Marinović, M., \& Rogulj, N. (2002). Position specific morphological characteristics of top-level male handball players. Collegium Antropologicum, 26(1), 219-227.

Táborský, F. (2007). The body height and top team handball players. EHF web Periodical. Retrieved October 15, 2019 from: http://activities.eurohandball.com.

Urban, F., \& Kandráć, R. (2013). The relationship between morphological profile and players' performance in elite female handball players. In: B. Kozlowska, A. Psintrou, \& H. Höritsch (Eds.), $2^{\text {nd }}$ EHF Scientific Conference "Women and Handball: Scientific and Analytical Approaches", (pp. 163-168). Vienna, Austria: European Handball Federation.

Van den Tillaar, R., \& Ettema, G. (2003). Effect of body size and gender in overarm throwing performance. European Journal of Applied Physiology, 91(4), 413-418.

Weber, J., Wegner, M., \& Wagner, H. (2018). Physical performance in female handball players according to playing position. German Journal of Exercise and Sport Research, 48(4), 498-507.

Young, W., \& Rogers, N. (2014). Effects of small-sided game and change-of-direction training on reactive agility and change-of-direction speed. Journal of Sports Sciences, 32(4), 307-314.

Zapartidis, I., Skoufas, D., Vareltzis, I., Christodoulidis, T., Toganidis, T., \& Kororos, P. (2009). Factors influencing ball throwing velocity in young women's handball players. Open Sports Medical Journal, 3, 39-43.

Ziv, G., \& Lidor, R. (2009). Physical attributes, physiological characteristics, on-court performances and nutritional strategies of female and male basketball players. Sports Medicine, 39, 547-568.

Šibila M., \& Pori P. (2009). Morphological characteristics of handball players. Collegium Antropologicum, 33, 1079-1086. 


\section{PROMENE U BRZINI, AGILNOSTI I SASTAVU TELA VRHUNSKIH RUKOMETAŠICA TOKOM TAKMIČARSKE SEZONE}

Rukomet je dinamičan Olimpijski sport u kom dominiraju aciklična kretanja (nagle promene pravca i smera, skokovi, prizemljenja, kontakt igra i dr.), a brzina i agilnost imaju značajnu ulogu u njihovoj uspešnoj realizaciji. Cilj istraživanja bio je da se utvrde promene u telesnom sastavu, brzini i agilnosti vrhunskih rukometašica tokom takmičarske sezone. Merni isntrumenti za procenu telesnog sastavabili su: masa tela, BMI, \% mišića i \% masti. Za merenje brzinskih sposobnosti (Sprint na $5 \mathrm{~m}, 10 \mathrm{~m}$ i 30m) $i$ agilnosti rukometašica (Koverta test bez lopte, Slalom pravolinijski bez lopte, Slalom pravolinijski sa loptom, Cik-cak 100 bez. lopte i Cik-cak 100 sa loptom) korišćen je sistem svetlosnih kapija. Utvrđivanje razlika između inicijalnog i finalnog merenja vršeno je pomoću Studentovog t-testa. Dobijeni rezultati pokazuju da je na kraju takmičarske sezone došlo do statistički značajnih promena $i$ slabijih rezultata u skoro svim ispitivanim varijablama. Jedino poboljšanje vrednosti bilo je u maksimalnoj brzini trčanja na 30m i agilnosti bez lopte (Koverta test i Slalom pravolinijski bez lopte). Preporuka autora je da se obrati pažnja na plan i program trenažnog procesa (primena aktivnosti visokog inteziteta opterećenja tokom cele sezone), kao i na pravilnu sportsku ishranu (smanjenje telesne mase treba da se odigrava istovremeno sa povećanjem mišićne komponente).

Ključne reči: telesni sastav, brzina, agilnost, promene, rukometašice. 